\title{
Analysis of Islamic-Based Human Development: Concept and Significance
}

\author{
Norullisza Khosim ${ }^{1}$, Azrin Ibrahim ${ }^{2}$, Mohd Shukri Hanapi ${ }^{3}$ \\ ${ }^{1}$ Centre for Islamic Development Management Studies (ISDEV), Universiti Sains Malaysia \\ ${ }^{23}$ Centre for Islamic Development Management Studies (ISDEV), Universiti Sains Malaysia \\ ${ }^{1}$ norulliszakhosim@usim.edu.my
}

Article History: Received: 11 January 2021; Accepted: 27 February 2021; Published online: 5 April 2021

\begin{abstract}
Current reality shows an increase in various problems afflicting society. This scenario is worrying and can jeopardise as well negatively affect human wellbeing. Islam emphasises a comprehensive development of human life without neglecting other aspects. One of these types of developments is human development (HD). Understanding the Islamic-based human development (IbHD) should be emphasised in order to implement a sustainable life. Hence, this study intended to identify the IbHD concept as well as its significance. This study employed the document research method for data collection by applying the content analysis approach for analysing data. Findings show that IbHD differs from conventional development (CD) because IbHD uses a development model outlined by the Quran and Sunnah, multi-dimensional, own its unique principles, also playing an important fundamental element in building quality humans in this world and in the afterlife.
\end{abstract}

Keywords: Human Development (HD), Islamic-based Development (IbD), Islamic-based Human Development (IbHD) Quran and Sunnah, Sustainability.

\subsection{Introduction}

In order for the ummah to achieve wellbeing and excellence, not only the economic development aspect needs attention but also various other aspects too. One of these aspects is the human development (HD) aspect. HD is one of the important fundamentals required for developing a society, nation and the ummah because excellence depends on the development actor who possesses commendable moral values. Developing an exceptional and spectacular human being is not an easy task but rather, it requires continuous effort and the process begins from the earliest days of a human being. Various methods have been introduced in efforts to achieve the outlined objectives and among them are the role of the family institution, education system, dissemination of information in the social media and etc.

When initiating these efforts, especially the development of exceptional humans, the basic element that should be given full consideration is Islamic-based development (IbD). Each development implemented should hold through to IbD to ensure the smooth implementation of a process is in line with the shari'ah that has been outlined, especially concerning the HD process. Hence, an understanding of the IbHD concept and its significance should focus and ensure that the excellence achieved not only concerns worldly affairs but also matters related to the afterlife.

\subsection{Definition of Human Development}

The term 'human development' is made up of two words, namely 'development' and 'human'. Development refers to actions or a particular development method (Kamus Dewan, 2013), or an expansion or enhancement from one situation to a better situation from all the aspects involved (Che Bakar Che Mat, 2007). Development is also an activity based on objectives and values aimed at enhancing human wellbeing in all dimensions (Syed Othman al-Habshi, 1992). Humans are creatures created by Allah SWT and given a mind to tell the difference between human dignity and status with the other creatures created by Allah SWT. The word 'insan' (humans) originated from several root words in Arabic, such as 'nasiya', 'uns' and 'anasa'. The word 'nasiya' means forget and is consistent with human characteristics that are synonymous with the nature of forgetting and neglecting. The word 'uns' means serenity, empathy and fondness, while 'anasa' means corporeal or tangible. This meaning is consistent with the characteristics of humans who have a heart and express feelings of serenity and empathy, while the human body is physically apparent to the human eye (Ibn Manzur, 2008).

Hence, the abbreviation HD mentioned in this study refers to the human development process that enhances selfquality not only by focusing on one dimension but multi-dimensional in nature (Nor Sahida Mohamad \& Sanep Ahmad, 2013). Specifically, development involves physical, emotional, spiritual and intellectual aspects (Fariza Md Sham \& Idris Zakaria, 2006; Kamarul Ami Jasmi, 2016), which focuses on development that is built according to the Islamic tasawur mould (Mohd Shukri Hanapi, 2017). In fact, all Muslims need to hold firmly to the IbHD because Islam encourages comprehensive development in every aspect of life (Nor Sahida Mohamad \& Sanep Ahmad, 2013), without focusing solely on the materialistic aspect. 


\subsection{Literature Review}

Numerous previous studies have examined IbHD. Studies related to HD included the HD concept based on the literary works and Muslim scholars thought, development concept from an Islamic perspective, importance of $\mathrm{HD}$, empowering HD through education, teaching and learning (PdP) as well as incorporating Islamic values into HD.

According to the literary works and Muslim scholars thought, study carried out by Zainudin Hashim (2018) analysed the thinking of Hassan al-Banna based on the scripture Majmu'ah Al-Rasail by focusing on discussions pertinent to the elements and aspects of HD, while Muhamad Alihanafiah Norasid (2016) had studied the thinking of Said Hawa based on his scripture Al-Asas Fi Al-Tafsir, which was related to divine human development, whereas Mohd Shafiee Hamzah (2012) had introduced the HD concept built by Sayyid Qutub.

In addition to the thinking's of Hassan al-Banna, Said Hawa, and Sayyid Qutub, the thinking's of Al-Mawardi, Syeikh Abdul Samad Al-Falimbani, and Al-Imam Al-Nawawi were also studied in order to introduce the HD concept outlined by these Muslim scholars. Siti Sarah Ahmad (2012) had basically dissected al-Mawardi thought related to HD by introducing several moral values that should be ingrained in every human in order to become exceptional humans. Shohana Hussin (2010) had highlighted six HD concepts that were introduced by Syeikh Abdul Samad Al-Falimbani covering various development aspects pertaining to knowledge, akidah, ibadah, seven parts of the human body namely the eyes, ears, tongue, stomach, genitals, hands and legs (anggota tujuh), spirituality and morality, also social etiquette. Kamarul Azmi Jasmi (2002) described the emphasis on the spiritual aspect based on two elements, namely the correct methodology as well as complete and accurate contents of a successful HD according to Al-Imam Al-Nawawi.

Besides discussions on HD found in literary works and Muslim scholars thought, the HD concept according to Islam from various aspects was also discussed by researchers. According to Islam, HD should be multidimensional in nature and focus on factors such as faith and piousness towards Allah SWT (Nor Sahida Mohamad \& Sanep Ahmad, 2013) because it is a benchmark for the most noble humans in the eyes of Allah SWT. Moreover, the spiritual aspect is the starting point for HD (Noor Shakirah Mat Akhir \& Muhammad Azizan Sabjan, 2014), which should also be the principal element in the materialistic aspect (Kamarul Azmi Jasmi, 2016). There are at least eight main fundamental elements required for human spiritual development, such as moral development projected towards Allah SWT, moral development projected towards humans, social development, development of living etiquette, development of ibadah, development of jihad, development of knowledge and development of knowledge permitted by Islam (Kamarul Azmi Jasmi \& et al, 2007).

According to Islam, the HD model is one of the sources that ensures the sustainability of ummah (Noor Shakirah Mat Akhir and Muhammad Azizan Sabjan, 2014; and Kamarul Azmi Jasmi, 2016), and produces a wider effect compared to the CD model (Nor Sahida Mohamad \& Sanep Ahmad, 2013). For example, there is a clear difference between development from the actor's perspective and the time-frame for the development cited in both these development models. Islam sees humans as the most important character in a development that should move in sync with development and cannot be separated from the framework because it covers the spiritual and physical aspects as well as worldly and afterlife aspects (Mohd Fauzi Hamat and Mohd Khairul Naim Che Nordin, 2012).

The fact is HD plays a significant role because it has a huge impact on individuals, society, organisations, the nation and the ummah. Baharom Mohamad \& Mohamad Johdi Salleh (2009) explained the importance of HD in the nation building context by explaining it from various perspectives, such as health, education, IPTA, ICT, economy, social, Islamic and moral perspectives. Ab Aziz Yusof \& Mutiara Dwi Sari (2017) also supported this finding by stating that HD based on an Islamic perspective should include both the physical and spiritual (mind and emotions) elements that produce pious humans characterised by amar makruf nahi mungkar, a clear mission, tawazun, sakinah, noble moral values as well as a generous and helpful attitude. Mohd Roslan Mohd Nor \& Zaiton Mustafa (2018) explained that from a holistic aspect, HD contributes to society's wellbeing and is required by humans to achieve happiness in this world and in the afterlife. Moreover, in the organisational context, this concept provides cogent suggestions for integrated solutions and is overall effective in providing better profits due to the maximum productivity and quality service provided by the staff or employees (Ilhaamie Abdul Ghani Azmi, 2009).

From the aspect of HD's importance, the empowerment of HD should be through education, teaching and learning (PdP) and various mediums that begin from childhood (Asmawati Suhid, 2007; Mustapha Kamal Ahmad Kassin \& et al, 2010; Ermizam Edni \& et al, 2010; Mohd Faeez Ilias \& Kamarul Azmi Jasmi, 2011; Siti Fatimah Ahmad \& Maimun Aqsha Lubis, 2015; and Mazlini Adnan \& et al (2016). These studies emphasised teaching etiquette, Islamic moral values and Islamic civilisation as well as focus on Islamic-based education in order to help build exceptional human development not only in academics but also good character, etiquette, moral values as well as noble values that are rarely practiced and easily forgotten by society. Mazlini Adnan \& et al (2016) also asserted the need to empower HD from the childhood level education perspective by introducing STEM in the student's curriculum. Moreover, lecturers are responsible for developing students of high quality by consolidating and improving the quality of PdP (Ermizam Edni \& et al, 2010). 
Mohd Yusof Othman (2012) stated that the Malay language plays a dynamic role in HD because it is based on strong core values, namely Islamic values. The Malay language is not only a mode of lingual communication used solely for delivering information but it is more than that because the Malay language is part of the national identity. Therefore, education, teaching and learning (PdP) involving the Malay language as well as Islamic education should be emphasised because Malaysia has critically invested in higher education and HD in efforts to produce a society that possess a noble sense of thinking, open thinking, incredible foresight and a high level of employability (high marketability) (Norhasni Zainal Abidin, 2014). In addition, appreciating and practicing the National Education Philosophy (FPK) concept should be emphasised in order to produce humans who possess all aspects of life and the capability of safeguarding the wellbeing of oneself, family, society as well as fellow Muslims (Saharia Hj. Ismail, 2015). In addition, a student's balanced personality and academic achievement should receive attention because these two elements are the core of HD (Nooraini Othman, 2018).

Besides empowering HD through the education system, assimilation of Islamic values should also receive attention because the importance of Islamic values incorporated into HD has tremendous effects on humans (Norullisza Khosim, Azrin Ibrahim \& Mohd Shukri Hanapi, 2020). For example, development of Quranic values through self and work values that produce excellent humans should be emphasised in HD because it is capable of enhancing performance and self-potential. In addition, the individual should be equipped with noble values and stay optimistic because the objective of development is not solely for materialistic purposes but rather acts as a method and tool for achieving a better quality of life as well as improving human civilisation (Rashidi Abbas \& Zilai Saari, 2016; and Haryati Shafii \& et al (2009). Besides that, moral values, mainly those projected towards Allah SWT, are significant and are values that motivate the development of human civilisation; hence, should be assimilated by each human (Kamarul Jasmi \& et al, 2004). A person's quality can be enhanced by adopting the evaluation of a narrator's concept according to the 'Ulum al-Hadith framework when developing a holistic and flexible individual (Khadher Ahmad, 2019).

Based on these discussions, it is clear that there are numerous literary works related to IbHD. Various concepts regarding HD have been introduced by Muslim scholars in the form of excellent human identity in this world and in the afterlife. The HD concept summarised by the Muslim scholars and described by researchers is IbHD because its concept is guided by the teachings of the Quran and Sunnah. Also, there are literary works that emphasise the importance of HD for every strata of society, which can be empowered through the education system and the PdP process. The assimilation of Islamic values must begin from an early age in order to build an excellent individual, not only for life in this world but also in the afterlife.

\subsection{Analysis and Discussions}

\section{The Islamic-based Human Development (IbHD) Concept}

Overall, the development and implementation of HD should be based on the Quran and Sunnah because Islam has its own virtues and strengths in every matter that has been divinely stipulated by the shari'ah. Muhammad Syukri Salleh (2003) argued that it will not be an IbD if it still adheres to the conventional method that has differing views on basic matters pertaining to development.

IbHD is a development process based on the supremacy of Allah SWT and its objective is to gain the blessings of Allah SWT, while its framework includes life in the spirit world, in this world and in the afterlife. There are at least seven fundamentals or principles that have been outlined, which are namely making Islamic worldview (tasawur) the development mould, humans as actors of development, the spirit world, this world and the afterlife as a development scale, knowledge about fardhu 'ain as a development framework, ibadah as a method of development, nature as a development tool, and achieving mardhatillah as the objective of development (Muhammad Syukri Salleh, 2003).

IbHD can be implemented according to various aspects, among them is understanding the IbHD concept, the education and PdP process as well as assimilating Islamic values. Neglecting HD would have a negative effect not only on the individual but also on society, the nation and human civilisation. This is because HD is the core element in national and societal development, while the core element in HD is spiritual development since spiritual progress is the main reason why Allah SWT created humankind. Allah SWT exhorted in the Quran, Surah al-Zaariyat, verse 56, meaning:

"And I did not create the jinn and mankind except to worship Me" (Al-Zaariyat: 51:56)

When pursuing developmental progress in various aspects, Islam does not neglect the world because the world is a place and its contents act as tools for HD. Hence, IbHD is a form of development that embraces maqasid alshari'ah, especially the five main aims, which is to preserve religion, the mind, life, descent or lineage and property. IbHD is an important fundamental aspect and its implementation guarantees a prosperous life in this world and in the afterlife. Allah SWT exhorted in Surah al-Qasas verse 77, meaning:

"But seek, through that which Allah has given you, the home of the Hereafter; and [yet], do not forget your share of the world. And do good as Allah has done good to you. And desire not corruption in the land. Indeed, Allah does not like corrupters". 
[Al Qasas, 28:77]

Based on Surah Al-Qasas Verse 77, it is clear that Allah SWT does not forbid humans from thinking about worldly affairs because the world is where humans have rights and responsibilities that have to be exercised, observed and fulfilled. Allah SWT has reminded humans that they should use what is bestowed on them as a way for reaping profits or benefits in the afterlife and avoid damaging or deleterious circumstances in this world culminating from management and administrative failures (Ibn Kathir, 1998).

Every changes, development and progress based on Islam refer to the return to true and genuine Islam that has been practiced and embraced by the Prophet SAW as well as noble companions, the tabi' in and the tabi' tabi'in as well as the mukminin and muslimin after them until today (Al-Attas, 1977). Hence, there will be no changes or progress made by a person, nation, society or civilisation unless there are sincere efforts to carry out the changes according to the promise made by Allah SWT, as mentioned in Surah Ar-Ra'd, Verse 11.

“... For him [i.e., each one] are successive [angels] before and behind, protecting them by Allah's command. Indeed, Allah would never change a people's state (of favour) until they change their own state (of faith). And if it is Allah's Will to torment a people, it can never be averted, nor can they find a protector other than Him ".

Al-Ra'd, 13:11)

The Significance of Islamic-based Human Development (IbHD)

Firstly, the significance of IbHD can be construed from the sources that act as main references when building the IbHD concept, namely the Quran and Sunnah. Both the Quran and Sunnah are the main sources in Islamic jurisprudence that pose as a guideline for a human's journey of life. Belief in these two main sources, especially for a Muslims, should be emphasised when implementing IbHD because the Prophet SAW exhorted in a Hadith, as follows:

"I have left behind two things so that you all do not go astray forever as long as you believe in these two things, namely Allah's scripture and the Prophet's Sunnah"

(Narrated by Imam Malik)

Secondly, the significance of IbHD can be evaluated based on seven fundamental principles used in building the IBHD concept, as outlined by Muhammad Syukri Salleh (2003) in the IbHD concept. It clearly states the significance of the IbHD model in building excellent humans compared to using the CD model because the CD model is unsuitable for implementation in an Islamic society since its development process is usually horizontally analysed, which only involves the inter-human and human-to-nature relationships (Muhammad Syukri Salleh, 2003). Hence, IbHD must be well understood in order to help implement HD according to the guidelines stipulated by shari'ah and to then produce humans who are excellent in this world as well as in the afterlife, because human life does not end in this world but continues into the afterlife. Without an understanding about the actual IbHD concept, the concern is that the desired objectives are not achieved after the implementation, which leads to development that does not fulfil Islamic guidelines. Each element related to Islam and Muslims should take a certain path and adopt solutions outlined by Islam. This is because the Islamic worldview has three important fundamentals that should be adhered to, namely Allah SWT is the Creator, humans are creatures and nature is also a creature, which incidentally are fundamentals that contradict the CD model. The CD model is moulded according to Western values that do not advocate the belief in Allah SWT as well as the assumption that humans are economic creatures that focus only on inter-human and human-to-nature relationships (Muhammad Syukri Salleh, 2003). Thus, the concept of IbHD and its significance can be concluding as follow Figure 1

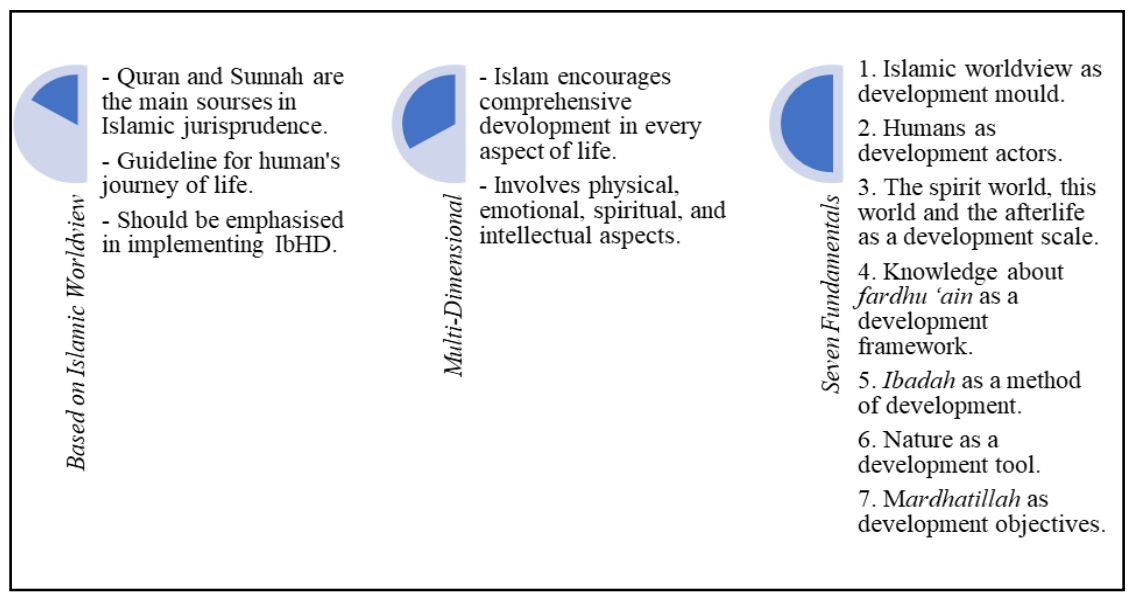

Figure 1: Islamic-based Human Development (IbHD) Concept and Significance 


\subsection{Conclusion}

It can be concluded that IbHD is a development concept that serves as a guide and a principle of life, especially for Muslims, because it is a concept based on the Quran and Sunnah as well as a demand made upon all Muslims by Islam. Each designation stipulated in the Quran and Sunnah is an important fundamental element that ensures the sustainability of a society and civilization. The belief in these two main sources must be strengthened in order to face life in the globalisation era that is filled with challenges and obstacles. The objectives of life and a true understanding of the IbHD concept and significance must be constantly emphasised so that the implementation process does not deviate from the ultimate truth.

\section{Acknowledgement}

Thank you to the Universiti Sains Malaysia (USM) for the financial supports through Short Term Grant, Account No: 304/CISDEV/6315131 - Titled Position of Hisbah and Negative Perceptions of Islamic Development Institutions in Malaysia

\section{References}

1. Al-Quran Al-Karim.

2. Ab Aziz Yusof \& Mutiara Dwi Sari. (2017). Pembangunan Modal Insan Daripada Perspektif Islam: Impak Kepada Pengurus. Malaysian Journal of Social Sciences and Humanities (MJ - SSH).

3. Syed Muhammad al-Naquib Al-Attas. Islam: Faham Agama dan Asas Akhlak. Kuala Lumper: Angkatan Belia Islam Malaysia (ABIM).

4. Asmawati Suhid. (2007). Pengajaran Adab Dan Akhlak Islam Dalam Membangunkan Modal Insan. Jurnal Pengajian Umum. Vol 8.

5. Baharom Mohamad \& Mohamad Johdi Salleh. (2009). Pembangunan Modal Insan Sebagai Satu Pelaburan Penting Dalam Konteks Pembinaan Negara. Prosiding "Seminar Pembangunan Modal Insan 2009".

6. Ermizam Edni \& et al. (2010). Pembangunan Modal Insan Melalui Pengajaran Dan Pembelajaran. Seminar Penyelidikan dan Inovasi.

7. Haryati Shafii \& et al. (2009). Pembangunan Modal Insan Ke Arah Meningkatkan Kualiti Hidup Masyarakat. International Conference On Human Capital Development.

8. Ilhaamie Abdul Ghani Azmi. (2009). Human Capital Development And Organizational Performance: A Focus On Islamic Perspective. Jurnal Syariah. Vol. 17. No. 2.

9. Imaduddin Abu Al-Fida' Ismail bin Kathir. (1998). Tafsir Al-Quran Al-Adzim. Beirut: Dar Al-Arqam bin Abi Al-Arqam.

10. Kamarul Azmi Jasmi \& et al. (2007). Pembangunan Modal Insan Yang Sempurna Menurut Perspektif Al-Imam Al-Nawawi. Seminar Antarabangsa Peradaban Melayu Ke-3.

11. Kamarul Azmi Jasmi \& et.al. (2004). Pendidikan Akhlak Kepada Allah SWT Nadi Penggerak Pembangunan Peradaban Insan. https://www.researchgate.net/publication/277255994.

12. Kamarul Azmi Jasmi. (2002). Paradigma Al-Imam Al-Nawawi Dalam Pembangunan Insan: Satu Kajian Teks Terhadap Kitab Riyad Al-Solihin. Disertasi Sarjana, Fakulti Sastera dan Sains Sosial, Universiti Malaya.

13. Kamarul Azmi Jasmi. (2016). Pembangunan Insan Daripada Perspektif Islam. In Kamarul Azmi Jasmi (Ed.), Ensiklopedia Pendidikan Islam (Edisi Pertama ed., pp. 102-107). Skudai Johor: Fakulti Tamadun Islam, Universiti Teknologi Malaysia \& Persatuan Cendiakiawan Pendidikan Islam Malaysia (AIES).

14. Kamarul Azmi Jasmi. (2016). Pembangunan Akhlak. In Kamarul Azmi Jasmi (Ed.), Ensiklopedia Pendidikan Islam (Edisi Pertama ed., pp. 99-100). Skudai Johor: Fakulti Tamadun Islam, Universiti Teknologi Malaysia \& Persatuan Cendiakiawan Pendidikan Islam Malaysia (AIES).

15. Kamarul Azmi Jasmi. (2016). Pembangunan Insan daripada Perspektif Islam. In Kamarul Azmi Jasmi (Ed.), Ensiklopedia Pendidikan Islam (Edisi Pertama ed., pp. 102-107). Skudai Johor: Fakulti Tamadun Islam, Universiti Teknologi Malaysia \& Persatuan Cendiakiawan Pendidikan Islam Malaysia (AIES).

16. Khadher Ahmad. (2019). Kualiti Individe Dalam Pembangunan Insan Menurut Kerangka 'Ulum alHadith: Satu Analisis. Jurnal Usuluddin. Vol. 47 (Khas)

17. Mazlini Adnan \& et al. (2016). Memperkasa Pembangunan Modal Insan Malaysia Di Peringkat KanakKanak: Kajian Kebolehlaksanaan dan Kebolehintegrasian Pendidikan STEM Dalam Kurikulum PERMATA Negara. GEOGRAFIA Online Malaysian Journal Of Society And Space. Vol. 12. Bil. 1.

18. Mohd Faeez Ilias \& Kamarul Azmi Jasmi. (2011). Peranan Pendidikan Islam Dalam Pembangunan Modal Insan Kelas Pertama. Persidangan Kebangsaan Sains Sosial.

19. Mohd Fauzi Hamat \& Mohd Khairul Naim Che Nordin. (2012). Tinjauan Kepentingan Pembangunan Modal Insan Di Malaysia. https://umexpert.um.edu.my/file/publication/00002849_82304_82803.pdf [Accessed at: 11 September 2019]. 
20. Mohd Roslan Mohd Nor \& Zaiton Mustafa. (2018). Pembangunan Individu Menurut Ibnu Sina: Analisis Terhadap Karya-Karya Terpilih. Jurnal Pengurusan dan Penyelidikan Fatwa. Special Edition.

21. Mohd Shafiee Hamzah. (2012). Konsep Perekayasaan Modal Insan Menurut Sayyid Qutub: Analisis Terhadap Fi Zilai Al-Quran. Tesis Kedoktoran, Akademi Pengajian Islam, Universiti Malaya.

22. Mohd Yusof Othman. (2012). Pengajian Melayu: Ke Arah Memperkasakan Modal Insan. Jurnal Melayu. Vol. 9.

23. Muhamad Alihanafiah Norasid \& Mustaffa Abdullah. (2019). Gagasan Pembangunan Modal Insan Rabbani Oleh Said Hawa Dalam Al-Asas Fi Al-Tafsir: Ke Arah Pemerkasaan Kader Dakwah. Jurnal Usuluddin. Vol. 47 (Khas).

24. Muhammad Fuad 'Abdul Bâqi. (1994). Mu‘jam Al-Mufahras Li Al-Fadz Al-Quran Al-Karim. Beirut: Dar Al-Fikr.

25. Muhammad Syukri Salleh. (2003). 7 Prinsip Pembangunan Berteraskan Islam. Kuala Lumpur: Zebra Editions Sdn. Bhd.

26. Mustapha Kamal Ahmad Kassin \& et al. (2010). Pembangunan Modal Insan Dan Tamadun Islam Dari Perspektif Pendidikan Guru. Proceesidings of The 4th International Conference on Teacher Education.

27. Noor Shakirah Mat Akhir \& Muhammad Azizan Sabjan. (2014). Pembangunan Modal Insan Dari Perspektif Kerohanian Agama: Islam Sebagai Fokus. Journal of Human Capital Development.

28. Nooraini Othman. (2018). Keseimbangan Personaliti Dan Akademik Sebagai Teras Pembangunan Modal Insan. http://eprints.utm.my/id/eprint/17876/1/Jurnal_UiTM Keseimbangan_Personaliti_dan_Akademik_sebagai_Teras_Pembangunan_Modal_Insan. [Accessed at: 11 September 2019].

29. Nor Sahida Mohamad \& Sanep Ahmad. (2013). Pembangunan Menurut Perspektif Islam: Satu Analisis Awalan. Prosiding PERKEM VIII, Jilid 1.

30. Norhasni Zainal Abidin. (2014). Senario Pembangunan Modal Insan Dalam Pendidikan Tinggi Di Malaysia. Jurnal Kajian Pendidikan. Vol. 4. Bil. 1.

31. Norullisza Khosim, Azrin Ibrahim \& Mohd Shukri Hanapi. (2020). Peranan Nilai-Nilai Islam Dalam Pembangunan Insan Berteraskan Islam. Journal od Islamic, Social, Economics and Development (JISED). Vol.5. No. 29.

32. Rashidi Abbas \& Zilai Saari. (2016). Pembangunan Nilai Qurani Dalam Kalangan Mahasiswa Universiti Malaysia Pahang Menerusi Nilai Diri dan Kerja. International Journal of Humanities Technology and Civilization (IJHTC).

33. Saharia Ismail. (2015). Pembangunan Insan Dalam Falsafah Pendidikan Kebangsaan. Journal of Human Capital Development. Vol. 8. No. 2.

34. Shohana Hussin. (2010). Pemikiran Pembangunan Modal Insan Dalam Kitab Hidayah Al-Salikin: Kajian Teks dan Kontekstual. Tesis Kedoktoran, Akademi Pengajian Islam, Universiti Malaya.

35. Siti Fatimah Ahmad \& Maimun Aqsha Lubis. (2015). Islam Hadhari Dalam Pendidikan Pembangunan Modal Insan Di Malaysia: Satu Analisa Epistimologi. Jurnal Hadhari. Vol. 7. No. 1.

36. Siti Sarah Ahmad. (2012). Adab Al-Riyadah Wa Al-Istislah Dalam Pembangunan Modal Insan Menurut Al-Mawardi Dalam Karya Adab Al-Dunya Wa Al-Din. Disertasi Sarjana, Fakulti Sastera dan Sains Sosial, Universiti Malaya.

37. Zainudin Hashim. (2018). Pendekatan Pembangunan Insan Menurut Hasan Al-Banna (m. 1949) Menerusi Kitab Majmu'ah Al-Rasail. Tesis Kedoktoran, Akademi Pengajian Islam, Universiti Malaya. 